\title{
Expanding the ADCY5 phenotype toward spastic paraparesis
}

\author{
A mutation in the M2 domain
}

Anne J.E. Waalkens, MD, Fleur Vansenne, MD, PhD, Annemarie H. van der Hout, MD, PhD, Rodi Zutt, MD, Jeroen Mourmans, MD, Eduardo Tolosa, MD, PhD, Tom J. de Koning, MD, PhD, and Marina A.J. Tijssen, MD, PhD

Neurol Genet 2018;4:e214. doi:10.1212/NXG.0000000000000214

Patients with an $A D C Y 5$ gene mutation reveal a heterogenous clinical presentation including axial hypotonia, motor milestone delay, fluctuating dyskinesias, dystonia, and/or myoclonus with episodic exacerbations during drowsiness and sleep. ${ }^{1,2}$ Phenotype-genotype correlations and somatic mosaicism are suggested to explain the wide phenotypic spectrum. ${ }^{1}$

The ADCY5 gene encodes 1 of 9 membrane-bound adenyl cyclases converting adenosine triphosphate to cyclic adenosine- $3^{\prime}, 5^{\prime}$-monophosphate, the second messenger in a range of cellular activities. ${ }^{3}$ The $A D C Y 5$ protein contains 2 transmembrane domains, M1 and M2, and 2 bipartite cytoplasmic domains, $\mathrm{C} 1$ and $\mathrm{C} 2$. Pathogenic mutations have been described in domains $\mathrm{C} 1$ and $\mathrm{C} 2{ }^{1,2}$ Mutations are likely to have a gain-of-function effect based on increased cyclic adenosine- $3^{\prime}, 5^{\prime}$-monophosphate accumulation. ${ }^{4}$

The present report describes 3 cases of $A D C Y 5$ dyskinesia to further illustrate the clinical spectrum: a new phenotype, i.e., spastic paraparesis due to a mutation located in the M2 domain; case 1 , case 2 , and case 3 show previously described mutations in the $\mathrm{C} 1$ domain of the ADCY5 protein. Their phenotypes show important similarities to previous cases, with the addition of the psychiatric symptoms of the patient in case 3.

\section{Case 1}

A 40-year-old woman was referred to our clinic with a 6-year history of progressive fatigue, painful movements, and muscle weakness of the lower limbs. History revealed delayed ability to sit independently until the age of 2 years, most likely due to early axial hypotonia, with subsequent catching up of motor development. Family history revealed no movement disorders. Neurologic examination showed spastic paraparesis, with hyperreflexia, hypertonia in the legs, and extensor plantar reflexes. There was mild dystonic posturing of the right foot while walking and writer's cramp of the right hand. As the dystonic features were not recognized as such before, the age at onset is not clear. MRI of the brain and spine and metabolic blood examination were unremarkable.

Whole-exome sequencing revealed a c.2722G $>$ A, p.(Glu908Lys) mutation in the ADCY5 gene. Her mother is mosaic for the mutation in peripheral blood (proportion mutation: wild type about 1:3) without a relevant medical history or current complaints.

\author{
Correspondence \\ Prof. Dr. Tijssen \\ m.a.j.de.koning-tijssen@umcg.nl
}




\section{Case 2}

A 1.5-year-old girl was presented to our clinic with motor milestone delay and dyskinesias. Pregnancy and delivery were unremarkable. Hypotonia and involuntary movements were first noticed at the age of 9 months. Family history was negative. Neurologic examination showed axial hypotonia and generalized chorea, more pronounced by action, with facial involvement. There was hyperreflexia without spasticity. Mother described exacerbations of dyskinesia during sleep. Genetic testing revealed a "de novo" previously reported c.1252C $>\mathrm{T}$ p.(Arg418Trp) mutation in the ADCY5 gene. ${ }^{1,2}$

\section{Case 3}

A 16-year-old young woman was presented to the outpatient's clinic in Barcelona with episodic dyskinesias with oral involvement since the age of 18 months. At this age, she started walking independently with frequent falls. From 12 years of age, she developed tics, coprolalia, and prominent obsessive compulsive and anxiety disorder with phobias. At the age of 16 years, she presented with nonfluent speech, myoclonus, and chorea of the face and upper limbs and mild dystonic posturing of the limbs with episodic exacerbations. Family history revealed no movement, behavioral of psychiatric disorders. Genetic testing, using a dystonia panel, i.e., combined "next-generation" and Sanger sequencing method, showed a previously described c.1253G $>$ A p.(Arg418Gln) mutation in the ADCY5 gene. ${ }^{1,2}$

The 3 new ADCY5 cases support the wide phenotypic presentation of $A D C Y 5$ gene mutations in the literature. We add another phenotype, i.e., spastic paraparesis due to a mutation in the M2 domain of the ADCY5 protein (case 1). This mutation is predicted pathogenic by in silico prediction tools and is absent in available data sets of population controls.

Spasticity, hyperreflexia, and bilateral extensor plantar reflexes were mentioned as additional features in several cases with mutation(s) in a cytoplasmic (C) domain. ${ }^{2,5,6}$ The somatic mosaicism present in the index's mother demonstrates that mosaicism can lead to a (much) milder to no phenotype at all. ${ }^{1}$ Future studies are of interest to detect the relevance of $A D C Y 5$ mutations in patients with paraparesis.

Cases 2 and 3 show mutations in the $\mathrm{C} 1$ domain of the $A D C Y 5$ gene. These 2 mutations have been previously described with comparable dyskinetic phenotypes ${ }^{1,2}$; however, case 3 patient's (prominent) psychiatric symptoms are distinctive. If the psychiatric manifestations can be ascribed to the ADCY5 phenotype remains unclear, given these prevalence of psychiatric disorders in the general population. An association between $A D C Y 5$ mutations and psychiatric symptoms is conceivable.

Our 3 cases further support the conclusion of a heterogenous phenotype and a possible phenotype-genotype correlation as suggested in $A D C Y 5$-mutation-associated disease.

\section{Author contributions}

Anne J.E. Waalkens: article design and data description. Fleur Vansenne and Annemarie H. van der Hout: critical revision of the manuscript for intellectual content. Rodi Zutt: acquisition of patient data and critical revision of the manuscript for intellectual content. Jeroen Mourmans: acquisition of patient data. Eduardo Tolosa and Tom J. de Koning: acquisition of patient data and critical revision of the manuscript for intellectual content. Marina A.J. Tijssen: data supervision, acquisition of patient data, and critical revision of the manuscript for intellectual content.

\section{Study funding}

No targeted funding reported.

\section{Disclosure}

A.J.E. Waalkens, F. Vansenne, A.H. van der Hout, R. Zutt, and J. Mourmans report no disclosures. E. Tolosa has received speaker honoraria from UCB, Boehringer Ingelheim, Novartis, Abbott, Medtronic, Solvay, GSK, and Teva; has served on the editorial board of the Journal of the Neurological Sciences; holds a patent for Method for the sub-classification of patients suffering from Parkinson disease; and has served as a consultant for the Michael J. Fox Foundation for Parkinson's Disease, Novartis, UCB, Abbott, and Teva. T.J. de Koning has received speaker honoraria from Actelion Pharmaceuticals and Nutricia Medical Nutrition and has received grants from the Metabolic Power Foundation and Actelion Pharmaceuticals. M.A.J. de KoningTijssen has served on the editorial boards of Frontiers of movement disorders, Clinical Movement Disorders, and Basal Ganglia; has received research support from Ipsen, Allergan, Medtronic, Merz, DystonieNet, Actelion, the Dystonia Medical Research Foundation, Phelps Stichting, Netherlands Organisation for Health Research and Development (ZonMw), Fonds Nuts-Ohra, Princes Beatrix Muscle fund, Dystonie Vereniging, Hersenstichting, Fonds Psychische gezondheid, the Jacques and Gloria Gossweiler Foundation, the Science Foundation Dystonia Society, Mental Health, the Phelps Foundation, Beatrix Children Hospital Fund, and Healthy Aging Fund UMCG; has received unrestricted grants from Actelion, Merz, Ipsen, Allergan Pharmaceutics, and Medtronic; and has received travel funding/ speaker honoraria from the Merz expert meeting in Paris, January 2016, and Ipsen. Funding information and disclosures are provided at the end of the article. Full disclosure form information provided by the authors is available with the full text of this article at Neurology.org/NG.

Received May 23, 2017. Accepted in final form December 13, 2017.

\section{References}

1. Chen DH, Méneret A, Friedman JR, et al. ADCY5-related dyskinesia: broader spectrum and genotype-phenotype correlations. Neurology 2015;85:2026-2035.

2. Chang FCF, Westenberger A, Dale RC, et al. Phenotypic insights into ADYC5associated disease. Mov Disord 2016;31:1033-1040.

3. Chen YZ, Friedman JR, Chen DH, et al. Gain-of-function ADCY5 mutations in familial dyskinesia with facial myokymia. Ann Neurol 2014;75:542-549.

4. Iwamoto T, Okumura S, Iwatsubo $\mathrm{K}$, et al. Motor dysfunction in type 5 adenylyl cyclase-null mice. J Biol Chem 2003;278:16936-16940.

5. Carapito R, Paul N, Untrau M, et al. A de novo ADCY5 mutation causes early-onset autosomal dominant chorea and dystonia. Mov Disord 2015;30:423-427.

6. Carecchio M, Mencacci NE, Iodice A, et al. ADCY5-related movement disorders: frequency, disease course and phenotypic variability in a cohort of peadiatric patients. Parkinsonism Relat Disord 2017;41:37-43. 


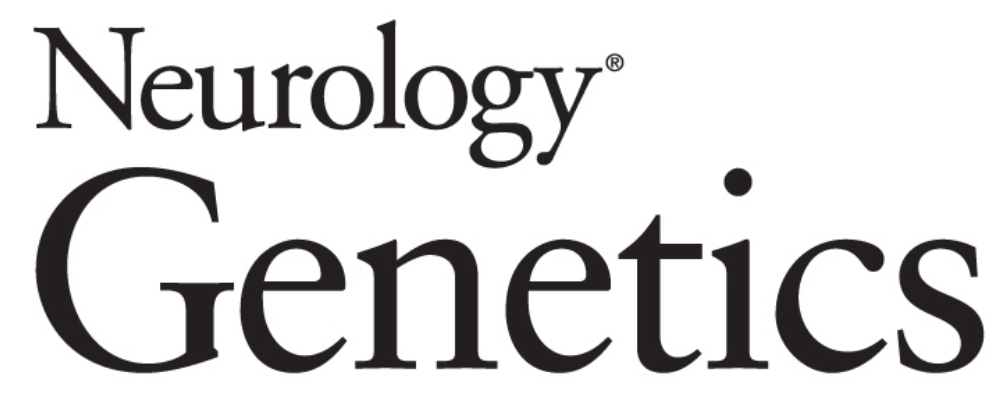

\section{Expanding the ADCY5 phenotype toward spastic paraparesis: A mutation in the M2 domain}

Anne J.E. Waalkens, Fleur Vansenne, Annemarie H. van der Hout, et al.

Neurol Genet 2018;4;

DOI 10.1212/NXG.0000000000000214

\section{This information is current as of January 24, 2018}

\section{Updated Information \&} Services

\section{References}

Citations

Subspecialty Collections

Permissions \& Licensing

Reprints including high resolution figures, can be found at: http://ng.neurology.org/content/4/1/e214.full.html

This article cites 6 articles, 1 of which you can access for free at: http://ng.neurology.org/content/4/1/e214.full.html\#\#ref-list-1

This article has been cited by 1 HighWire-hosted articles: http://ng.neurology.org/content/4/1/e214.full.html\#\#otherarticles

This article, along with others on similar topics, appears in the following collection(s):

\section{All Genetics}

http://ng.neurology.org//cgi/collection/all_genetics

Spastic paraplegia

http://ng.neurology.org//cgi/collection/spastic_paraplegia

Information about reproducing this article in parts (figures,tables) or in its entirety can be found online at:

http://ng.neurology.org/misc/about.xhtml\#permissions

Information about ordering reprints can be found online: http://ng.neurology.org/misc/addir.xhtml\#reprintsus

Neurol Genet is an official journal of the American Academy of Neurology. Published since April 2015, it is an open-access, online-only, continuous publication journal. Copyright Copyright @ 2018 The Author(s). Published by Wolters Kluwer Health, Inc. on behalf of the American Academy of Neurology.. All rights reserved. Online ISSN: 2376-7839.

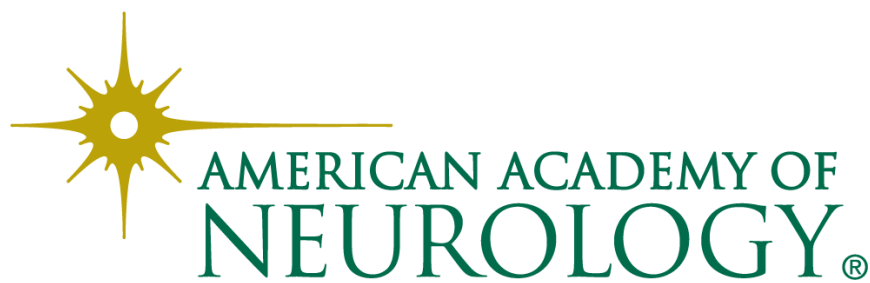

